be diminished, perhaps cven abolished; and (6) that the hospital authorities must not forget in delegating their duties of scrutiny that they are primarily responsible to the charitable public for the proper expenditure of the monies subscribed. I am, Sirs, yours faithfully,

$$
\text { F. HARRIS WHITE, }
$$

Nov. 1st, 1904. Honorary Secretary, East London Medical Society.

\section{INTOLERABLE INGRATITUDE.}

\section{To the Editors of THE LANCET.}

SIRs,-It seems to me that the wide publicity of your columns may be well invoked effectively to emphasise the following statement of protest which $\mathbf{I}$ addressed to $\mathbf{M r}$. Justice Lawrance in the King's Bench Division of the High Court in the case of Buckley, a cabman, versus Evans, a butcher, to attend which under subpœna the whole of my work and engagements and my patients' convenience were deranged through last week.

My Lord, before being sworn, I wish, with all respect to yoursel ${ }^{f}$ and your office, to make a statement emphatically protesting, on behal an myself, as a humble representative of so many of the most famous in my profession, who give cheerfully, freely, unstintingly, and without any money recompense, of the best of our professional skill, time, axperience, and judgment, for the gratuitous relief of the poor and poorest, with physical ills or injuries.

It seems to me, my Lord, that, to enforce my attendance here, as a common witness, under subpona served, with conduct coin, on me, on the front steps of the hospital, as it I were a writted rogue, on behal of the plaintiff whose case, as to its medical needs, it is alleged, received my charitable attention there, is a gross prostitution of philanthropy, an altogether indecent assault, an intolerable, if not indefensible ingratitucle; incomparably more base and contemptible than that of the cur which bites the hand that feeds him.

I hare represented to the plaintiff's solicitor and counsel that attending here as I am, and have been every day this week, to the total derangement of all my protessional work, under subpeena as a common witness, I shall testify only to fact, which cannot adrance the plaintiff' cause, and that I shall not give any opinion which would entitle me to that consideration, as an expert witness, which I exact, as I am entitled to do, when engaged in that capacity.

Mr. Justice Lawrance, assuring me of his full sympathy, remarked that the poor cabman probably believed my evidence would be very material to his case and he, not being able to pay expert witnesses' fees, had done what it was within his power to do to secure the advantage of my testimony and I had now only to be sworn and to answer the questions put to me. I replied: "Certainly, my Lord, my attendance has been exacted; my evidence as to matters of fact, but not as to any matter of opinion, is available."

The ensuing examnination resulted in my recognising a memorandum (privileged) which I had courteously made on the card of the plaintiff's doctor, an old student of mine, which it was alleged the plaintiff, whom I was not asked to identify, had brought to me on one of the occasions when it was alleged I had seen him, but not necessarily myself examined him, at the Royal Fye Hospital. Of course I would recall nothing to do with the patient, a possible one of the many thousands of hospital patients attended by me, and I had, of course, been careful not to risk reviving. by reference to hospital records, my memory as to the plaintiff's alleged visits to the hospital and my observations thereon.

Anything approaching to the frequent repetition of such outrageously vulgar tactics as those by which I was victimised last week would necessarily preclude busy medical men from exposing themselves thereto by that whole-hearted gratuitous professional devotion with which it is our pride and pleasure to be able to serve the afflicted poor. Such a calamity cannot be calmly contemplated, hence this further protest from Your obedient servant,

Savile-row, W., Nov. 2nd, $1904 . \quad$ Malcolm M. McHardy.

\section{MEDICAL CHARITIES.}

To the Editors of THE LANCET.

SIRS,-Sir William Broadbent's letter on behalf of the British Medical Benevolent Fund appeared just at the time of the recent French medical visit and may therefore have been overlooked by many of your readers. Allow me to call attention to the recently published lists of subscriptions for the entertainment of our French confrères, which yield the following results on analysis: 240 practitioners subscribed two guineas each and the majority made themselves liable for another two guineas should they be needed. Of these 240 London practitioners only 68 are subscribers to the British Medical Benevolent Fund and 98 are subscribers to Epsom College. Comment is not necessary, but it may be fairly suggested that the guaranteed guineas, if not needed, should be divided between the two medical charities.

Oct. 31st, 1904. I am, Sirs, yours faithfully,

\section{TEMPERANCE AND TYPHOID FEVER AT PHILADELPHIA.}

(From our Spectal SANITARY Commissioner.)

Philadel hia, U.S.A., Oct. 21st.

For many years the sanitary reputation of the city of Philadelphia has been open to one serious reproach. Its beautiful streets, its monumental town hall, the wealth and prosperity of its commercial men, and the virtues of its Quaker population have not served to conceal the fact that the people derived their drinking water from a sewage-contaminated river and suffered severely in consequence. This is the more unfortunate as the exaggerated phases of the temperance movement are more fully exemplified in the town of Philadelphia than in most places. Here on Sundays no wine or beer can possibly be obtained, not even in the traveller's own hotel. It is true that if he is confined to his bedroom, and presumably ill, alcoholic beverages may be brought to him but not at his dinner if served in the dining room or in any other public or semi-public place. At meals in the majority of private houses the only beverage served is iced water. In the estimation of many to call for wine or beer at meal times would be to lose caste. But before attempting to transform the inhabitants into water drinkers the very first thing to be done was to secure an absolutely pure and abundant water-supply. To force the public to drink diluted sewage instead of beer can scarcely be defined as a temperance measure and its benefits are doubtful. Drunkenness is an abomination but the frequent occurrence of as many as 300 new cases of typhoid fever in the course of a single week is scarcely an improvement. It would take a good deal of dram drinking at saloon bars to produce as much mischief. The innocent temperate drinker might be allowed hygienic drinks such as pure wines and beers at his meals instead of being exposed to typhoid infection because of the drunken excesses of a small minority of the population. In any case the temperance movement has led to this, that even those who do occasionally drink alcohol in some form are also made to drink a large quantity of cold water. It is but natural to suppose that the pathogenic germ if taken in small quantities is less likely to be effective in producing disease. But if, in the hope of drinking water that has been boiled, coffee or tea is ordered the American waiter is sure to bring first a glass of iced water. Then, especially among the ladies, an extraordinary consumption of ice-creams takes place daily. In such circumstances the purity of the water-supply is a matter of primary importance and the temperance reformer should have seen to this first before attempting such legislation as would compel people to drink water when no pure water is obtainable.

The only water available in Philadelphia for drinking purposes is derived from the Delaware and Schuylkill rivers. The Schuylkill water is not filtered, and receives the crude sewage of Reading with its population of 79,000 and a number of other manafacturing and neighbouring towns. This is but a small river with insufficient water to purify by natural means the sewage with which it is contaminated. No wonder that Philadelphia possesses an unenviable reputation for the prevalence of typhoid fever. With its broad streets, its freedom from overcrowding and poverty, and, finally, with its very low marriage-rate and birth-rate, it should have an exceptionally small death-rate. Such, how ever, is not the case. The death-rate for the year 1903 amounted to 18.82 per 1000 and this is below the average for the last ten years-namely, $19 \cdot 13$ per 1000 of the population. The part that typhoid fever plays in this unfavourable state of affairs may be judged by the official statistics giving the figures as to the notifiable contagious diseases. These amounted last year to 3043 cases of diphtheria, an increase of 589 on the previous year ; 4188 cases of scarlet fever, an increase of 1029 over the preceding year; 1637 cases of small-pox, an increase of 295 in comparison with the preceding year; and no less than 8701 cases of typhoid fever, or 3695 more cases than in 1902. In the year 1900 the 